\title{
IDENTIFICATION AND ASSESSMENT OF KEY POLITICAL RISK FACTORS INFLUENCING CORPORATE PERFORMANCE OF MULTINATIONAL CONSTRUCTION COMPANIES IN NORTH-EASTERN, NIGERIA
}

\author{
${ }^{* 1}$ Adebiyi, O. J. and ${ }^{2}$ Sanni, A. G.
}

*1,2 Department of Quantity Surveying, University of Benin (UNIBEN), Benin City, Edo State, Nigeria.

${ }^{* 1}$ Email: adebiyiola@gmail.com ${ }^{* 1}$ Phone: 08037351597

${ }^{2}$ Email: agsanni@gmail.com Phone: 08037337901

\begin{abstract}
Multinational construction companies settled in African countries, especially Nigeria, to compete for infrastructural projects, in a bid to extend their services across their borders. The trans-border extension of the services offered by these multinationals exposes them to the political risk factors pertinent within the host-country. In order to survive the harsh realities of the political risk indicators operational in Nigeria, especially the North-eastern part of the country that has been plagued with civil unrest associated with the terrorist operations of Boko haram, it has become necessary to identify and manage these risk factors, to ensure the continuous survival of international construction companies in Nigeria. This paper seeks to identify and assess the prevalence of political risk factors influencing the corporate performance of international companies operating in the North-east of Nigeria. Data for the study was collected through structured questionnaires administered to 78 expatriate project managers from 6 international construction companies in 6 states in the North East of Nigeria. Collected data was analyzed using relative importance index and factor analysis. Findings revealed that terrorism, corruption, insurrections, sabotages and kidnapping were the top five risk factors with the highest frequency of occurrence. It was also revealed that terrorism, kidnappings, sabotages, corruption and change in government are the risk factors with the highest impact on operations in the region. It is therefore recommended that the federal, state and local governments should provide security for the lives, properties and investments in the region, companies should do more corporate social responsibilities and purchase political risk insurance cover to minimize their losses.
\end{abstract}

Keywords: Boko Haram, corporate performance, Northeast Nigeria, political risk, international construction companies

LICENSE: This work by Open Journals Nigeria is licensed and published under the Creative Commons Attribution License 4.0 International License, which permits unrestricted use, distribution, and reproduction in any medium, provided this article is duly cited.

COPYRIGHT: The Author(s) completely retain the copyright of this published article.

OPEN ACCESS: The Author(s) approves that this article remains permanently online in the open access (OA) mode.

QA: This Article is published in line with "COPE (Committee on Publication Ethics) and PIE (Publication Integrity \& Ethics)". 


\section{INTRODUCTION}

According to Aswathappa (2008), multinationals are constantly striving to break into international terrains and markets, by providing improved and innovative goods and services, in a bid to stay relevant in fast moving international economies. It is a trite in Decision Theory that every decision has its risks and the risk is largely influenced by external factors. Different countries have different jurisdictions, political, social and environmental risks that the corporate firms must manage as part of its business threats. The ability to control the various risk factors, which can affect the quality of service delivery, by these international construction companies, has been the major reason for their sustained success and the ineffective management of the risks, can lead to failure of these companies (Dikmen et al., 2007). Nigeria's economy was initially dominated by agriculture until the discovery and exploration of crude oil in 1973; oil became the major source of income to the country. A combination of Nigeria's population size and huge income makes her a potential economic force in Africa. Indeed, she is referred to as the Giant of Africa. Nigeria also has many other solid mineral deposits which are presently under exploited. This has made Nigeria, a Mecca for international companies, seeking comparative advantage or any means possible, to profit from the robust and aspiring economy.

Poor economic opportunities and illiteracy have exposed some African countries including Nigeria to violent social and political unrests. These unrests usually have political and/or religious undertones and their effects are devastating. Nigeria has unofficial fault lines dividing the country into the Muslim majority north and Christian majority south. In between these poles are mosaic of ethnic groups and faith affiliations in varying proportions. The North-Eastern (NE) has six states consisting of Borno, Yobe, Adamawa, Bauchi, Gombe and Taraba. Borno, Yobe and Adamawa states have witnessed terror-destructive activities of Boko Haram. Boko Haram which means 'western education is forbidden' in hausa (a language commonly spoken in the region) is a terrorist group whose primary mission is to establish an Islamic caliphate in the region. The group operation is violent, its agitations are militarized and its attendant humanitarian crisis is catastrophic. Between 2000 and 2014, Boko Haram has killed more than 20,000 people, destroyed private properties and public infrastructures like roads, bridges, public buildings, electricity installations, public water works amongst others (Olaniyan 2015). Nigerian military forces have been trying to contain $\mathrm{BH}$ and rehabilitate the destroyed infrastructure in the region. Government intervention programmes is massive and physical development requiring construction activities is increasing.

According to Omotola (2010), the government of Nigeria has sort ways to reduce the suffering of the populace in North East of Nigeria, by the provision and improvement of infrastructures in the region. This infrastructure lacuna in the North East of Nigeria has attracted various international construction companies to the region. These companies bid for intended projects and engage in on-going civil engineering and construction projects. In the quest to stay afloat and relevant in the Nigerian economy, international construction companies are constantly working on various construction projects in the North-eastern part of Nigeria; this has made them susceptible to political risk factors in the region. According to Aaron (2010) and Jackobsen (2010), international construction companies operating in the NE part of the country have been plagued with political and religious interference with their work. Osumah (2013) also added that, insurgencies in the North East of Nigeria have caused huge economic losses to international investors and the Nigerian Government. Buratai (2017) stated that the North East of Nigeria 
has lost \$9b (Nine billion Dollars) worth of investments by government, local and international investors due to the political instability in the region fueled by Boko Haram.

Political risks and its effects on international companies and projects are becoming severe in Nigeria. Research and policy thrusts on Boko Haram insurgency seem to be focusing on its political, religious, economic and military dimensions or combination of these. Studies that focus on the economic implication of Boko Haram insurgency on multinationals companies are scarce. To rebuild the damaged infrastructure like schools, hospitals, roads, bridges amongst others; the services of construction companies are needed. For some development, technology and expertise-related reasons, multinational construction companies are more involved in heavy engineering and infrastructure construction in Nigeria than the Nigerian-owned companies that are commonly called local contractors. In the light of the above, the study seeks to assess the exposure of multinationals construction companies operating in the NE part of Nigeria to political risks with a view to enhancing the corporate performance of the firms.

\section{LITERATURE REVIEW}

\section{POLITICAL RISK IN NORTH EAST (NE) NIGERIA: AN OVERVIEW}

The political turmoil caused by the Boko Haram sect in the NE part of Nigeria is a subject of concern for all business operating in the region. The state of chaos instituted by the Boko Haram Militia in the North East of Nigeria is a cankerworm that is slowly crippling developmental activities ongoing in the area. The advent of the ruinous sect and its nefarious activities has brought untold hardship, alienation, death, wanton destruction of property owned by government, private individuals, international companies, and threatens to sniff out western presence and education as it exists presently in the country (Olaniyan 2015; Adetoro 2012; Ogbonnaya and Ehigiamusoe 2013). The era of enormous technological advancements and knowledge transfer has made it imminent for international construction companies to cross borders in a bid to survive and succeed in the harsh economic climates and ever-dynamic world. According to Aswathappa (2008), corporate firms are constantly seeking ways to stay relevant and important in the constantly advancing and competitive global market, by providing various services borne out of technological breakthroughs, in various countries. Dikmen et. al., (2007), stated that the reason for the sustained accomplishments of certain multinationals in continually providing high quality services, on international projects, is in their ability to closely monitor and manage the various risk factors associated with their business.

Political risk can be described as risk spurred by political activities (Mortanges \& Allers 1996), government interference (Zhuang et al., 1998) and social occurrences (Howell \& Chaddick 1994). Political risk studies and forecasting is becoming popular with recent political activities occurring daily around the world. According to Kettles (2004), the close study of political risk is more significant than ever. However, Adebiyi (2011, p3), argued that there has been very little work done in regards investigating this area of knowledge especially in developing countries like Nigeria. Over time, political risk has been seen in different perspectives. Conceptual overview of political risks was carried out by (Howell 2001 \& Brink 2004), Deng and Low (2013) and Low et al. (2009) examined effect of political risk on foreign direct investments (FDIs), multinational enterprises (MNEs) and International joint ventures (IJVs) at country and industry level. Others are Rice \& Mahmoud (1990), Hashmi \& Guveli (1992), De Mortanges \& Allers (1996), Hood \& Nawaz (2004), Adebiyi (2011), Deng \& Low (2013) and Deng et al (2014). Most of these studies were carried out in developed countries without any relations to developing countries. An overview of literature shows 
paucity of research on political risk exposure of international construction companies operating in Nigeria, hence the need for the study.

\section{POLITICAL RISK}

In the past 30 years, political risk has transformed in various dimensions (MIGA, 2010). Investors and stakeholders have not paid keen attention to the consequences of the risk factors associated with political risk on their investments in diaspora, until recently. According to Weber (2010), The Iranian revolution and the oil crises in 1973 was a practical evidence of political risk negligence, this awakened political risk awareness in stakeholders thereby initiating the need for proper political risk analysis and assessment when investing in business ventures overseas. Nigeria also had its fair share of the repercussion of paying little attention to political risk factors, examples include; the challenges experienced by international firms exploring oil and gas in the Niger-delta, the boko haram insurgency in the North east of Nigeria. Across the African continent, there was the Aluminum companies and expropriation in Guinea. Lastly, the political wind of change that blew across Northern Africa and the middle east e.g. Bahrain, Libya, Egypt and Tunisia. These events have made political risk assessment a high priority amongst cross-border multinationals (Jakobsen, 2010; Alon et al., 2006).

To further comprehend the dynamics of political risk, a review of literature was carried out to explore the various definitions of political risk by researchers. According to Khattab et al. (2007), the vast amount of research on political risk can be seen in two perspectives; the first dimension defines political risk with regards government intervention in the operations of business ventures while the other defines it in relation to the incidences of any political and social events on international projects. The intervention of the host government in the operations of international firms is a political risk indicator. Butler and Joaquin (1998) defined political risk as the risk that a host-government will unpredictably alter the 'rules of the game' under which a business operates. However, Hood \& Nawaz, (2004) and Stosberg (2005) argued that, the idea of defining political risk with regards the intervention of the host government in businesses owned by international firms, may be limited for the dynamic nature of international business over time, also, risk is not all about positive variations but it must also comprise negative disparities.

Morales-Rios et al. (2009) simply defined political risk as the likelihood that political terrain in a country overseas will depreciate. However, Voelker et al. (2008) argued that, though political risk factors are driven by the host government's political actions, the negative effects of these risk factors affect international investments which include international construction firms and the general economy of the host country. Also, MIGA (2009) argued that the disturbances in the operations of international businesses by events associated with political risk forces could be inspired by the host government's attitude and the changes in the international business climate based on current or past events.

\section{POLITICAL RISK FACTORS}

Host Governments are key players in international business transactions. Host governments can alter the business environment of their countries by enforcing economic policies in a bid to secure their interests (Khattab et al., 2007). However, Jakobsen (2010) argued that countries could resolve to soft pedal for the sake of international companies operating in their countries; they opined that host countries can choose to formulate and enforce economic policies

\section{4 | Adebiyi and Sanni, 2020}


that can reduce foreign direct investments and hence cause economic hardship on the international construction investors operating in these countries. Political risk factors can be categorized into two; comprising Host governmentcaused risk factors and society-caused risk factors. Political risks relating to host government are those caused by the government that has jurisdiction over the territory that the company operates. Risk factors related to host governments are:

(i) Expropriation/Confiscation: According to Erkan (2011), expropriation is the resolution of a host government to seize one or several assets of an international business within a single area of economic activity. Jakobsen (2010) listed Chile, Ethiopia, Angola, Zambia, Zimbabwe, Peru and Dominican Republic as countries that have confiscated the assets of international firms.

(ii) Contract Repudiation: According to Choi et al. (2010), Host governments can breach the terms of reference and rules of engagements between them and the foreign companies involved in developmental projects and infrastructural provisions in their country by taking advantage of lacunas in their porous legal framework. An investigation carried out on Indonesia's power projects revealed that, breach of contractual agreements was the second highest political risk factor affecting the countries power projects (Voelker et al. 2008).

(iii) Currency Inconvertibility: Since 2015, Nigeria has experienced a shortage of hard foreign currency. Consequently, there is a restriction on international foreign exchange (forex) transfers and this affects international companies operating in the country. It has become impossible to repatriate their profits and dividends on investment to their home. Baas (2010) stated this policy could aid economic growth of the home country's economy, particularly if the country is facing economic hardship.

(iv) Ownership/personnel restriction: This happens when the host government make laws that make it compulsory for the indigenes or political office holders to own large shares in the company or impose a percentage of indigenes as staff in the company irrespective of their qualifications (Brink, 2004).

(v) Tax Restrictions: According to Zayed et al. (2007), this political risk factor is of great importance when investing or executing business transactions overseas. This must be analyzed carefully by international multinational firms operating in different climes because this risk factor can affect the level of profit recorded by these companies.

(vi) Import and Export Restrictions: Keillor (2005) stated that host countries could choose to enforce import and export restrictions due to industrial policies with the sole purpose of protecting domestic consumers of locally produced goods. Khattab et al. (2007) argued that import and export restrictions have negative effects on the balance of payments of the host country.

(vii) Corruption: The continuous existence of corrupt practices in Nigeria has become a bane of its development. This mostly involves greasing the palms of politicians and government officials in order to get contracts. Sometimes, it involves, agreeing to the terms of corrupt officials in a bid to ensure that approvals for payments for works are received as at when due. This act affects the quality of the project negatively.

(viii) Default in Payment: Delay in payments is a problem contractor have to deal with in Nigeria. The likelihood of recording payment delay in the projects executed in Nigeria is high and this usually results in cost and time overrun 
in projects (Adebiyi 2011). According to Brink (2004), the two sources where political risk can emanate from are politics and society. According to Alon and Herbert (2009) host society risk factors are mostly triggered by the citizens of the host country. Minor (2003) added that, risks associated with the host society are triggered in resistance to the actions of a constituted authority at the various levels of government, they adversely affect the level of performance and output of the international firms operating in the country.

Society-related political risks are those caused by the citizens of the country. The various risk factors associated with the society include:

(i) Terrorism: According to Chukwuma and Philip (2014), terrorism is the violence irrationally demonstrated by individuals, groups or states against human beings. It includes, unjustly terrifying, harming, threatening, killing of people and banditry. It also includes any violent act or threat carried out as part of individual or collective criminal plan aimed at terrifying or harming people or endangering their lives, freedom or security. Most of the time international companies operating on foreign soils are most vulnerable to this act of hostility. Terrorism negatively affects the level of production, labor availability, supply chain and business relations between countries (Czinkota 2010).

(ii) Kidnapping: Ngwama (2014) defined kidnapping as the illegal confinement or imprisonment of individuals against his or her own will by another individual or group of people, in such a way as to violate the confined individual's, right to be free from the restraint of movement. Obi (2009) and Aaron (2010) stated that the kidnapping of the staff of multinationals working in the Niger-Delta region by militants is a political risk factor of great concern. There has been an increase in the kidnap of local and especially foreigner workers in the Northern part of Nigeria since Boko Haram started terrorizing the region. According to Mohammed (2014), A Korean doctor and employees of an international construction company, Setraco Construction Company (SCC) were kidnapped and killed in Jama'are town in Bauchi State.

(iii) Riots and Insurrections: Bohstedt (2010) defined riots and insurrections as chaotic disturbance of the peace by three or more people, gathering by their own will, with collective intent to assist each other against any who oppose them. According to Khattab et al. (2007), the occurrence of this risk factor would lead to temporal or permanent closure of international construction companies operating in the affected areas, which translates to loss of revenue by the companies and the host country.

(vi) Revolutions, Coup d'état and civil wars: It can be deduced that the occurrence of this risk factor will lead to destruction of property, looting, injuries to persons and loss of lives, this would also lead to huge losses to local and international construction companies operating in the affected regions (Brink, 2004; Khattab et al., 2007).

(v) Destruction and Sabotage: This is always a product of riots, insurrections, revolutions, coup d'états. It has become a norm for private and public businesses to be torched and looted dry during these occurrences. In most cases, international businesses are always targeted for destruction. It also takes a twist in most cases when people target ongoing construction works for destruction. They sabotage the work in progress to make a political statement, hence, causing time and cost over-run and making these international businesses to run at a loss.

(vi) Change of Government: Change of government in Nigeria always comes with changes to existing programmes, projects and priorities. The new government can decide to cut funding to projects or sometimes abandon projects. This 
always spells doom for contractors who are involved with these affected projects. This is a very crucial risk factor to be considered by local and most especially international contractors.

\section{RESEARCH METHOD}

\section{STUDY AREA}

The study was conducted in the Northeastern part of Nigeria. This geo-political zone consists of six states, which include Adamawa, Bauchi, Borno, Gombe, Taraba, Yobe state. The northeast of Nigeria is slightly below a third of the countries land area. This region contributes significantly to the Gross Domestic Product (GDP) of the country from Agricultural products and exploration mineral resources. The agricultural products from this region are mainly for export and solid mineral resources have been discovered in large commercial quantities such as limestone, marble, kaolin, barite etc.

The mining of these minerals has begun at a very small scale but there is concerted effort by the federal government to attract foreign investors and companies to the area. In a bid to improve the infrastructure of the region, the government has embarked on various development projects, these include: The construction of highways, bridges, dams, water reservoirs, power plants, water networks, schools, hospitals etc. These projects have attracted contractors from within and outside the country. The region has experienced an influx of foreign expatriates in recent years.

\section{DATA COLLECTION}

The data employed for this study were collected through the use of a structured questionnaire administered to 78 expatriates project managers from the six states in the North east of Nigeria. The questionnaire was designed to capture the professional views of the project managers on the frequency and impact of occurrence of political risks on corporate performance of multinational construction companies operating in the northeastern region of Nigeria. Evaluation of both risk occurrence and impact was assessed based on an equidistant five-point likert scale comprising Very Low (VL), Low (L), Moderate (M), High (H) and Very High (VH). These project managers are directly involved in the design and construction of the various civil engineering infrastructural projects across the North East Nigeria. The data collection was also carried out through face-to-face interaction.

\section{DATA ANALYSIS}

Retrieved primary data were analyzed using the factor analysis and relative importance index (RII) for frequency and impact of occurrence objectives respectively. The criticality of the thirty risks that were identified from the literature was explored using Factor Analysis. Factor analysis was used to assess the multivariate relationship among the identified political risk factors. Principal Component Analysis (PCA) method of extraction was used to determine possible cluster relationships among the risk factors and Varimax with Kaiser Normalization method of rotation was employed to make factors easily interpretable. The rotation of variances converged in 23 iterations and factor analysis produced eight factor groupings with Eigen values of 1 and above. The significant groupings were selected, thereby reducing the groupings to the most significant five with eigen values (EV) ranging from 2,10 to 4.34'. The criterion used in determining the significance of groupings is the weighting of the EV. For a grouping to significant, its Eigen Value must not be less than 2.00. According to Hardcastle et al. (2004) and Public Administration Programme (PAP) 
(n.d.), low Eigen value is contributing little to the explanation of variance in the variables and may be ignored as redundant with more important factors.

The five groups that were selected produced a percentage variance explained (PVE) of $69.63 \%$ of the total variance explained (TVE). It can be deduced that the five grouping would be a good representative of the remaining three groupings that were considered insignificant.

\section{RESULTS AND DISCUSSION}

\section{FREQUENCY OF OCCURRENCE OF POLITICAL RISKS}

Table I shows the frequency of occurrence of political risk factors in the corporate practice of multinational construction companies operating in the North-Eastern Nigeria using factor analysis. The five groupings are presented in Table II in descending order of frequency of occurrence of the political risks. These were protectionism, insurgency, violent civil disorders, regime instability and corruption. Protectionism which implies giving government-back support to national companies over multinational companies has the highest frequency of occurrence. It has $3.34 \mathrm{EV}$ and $18.08 \% \mathrm{PVE}$ and is the risk factor that has the highest frequency of occurrence. Its components are expropriation, confiscation, contract repudiation, tax restriction, import /export restriction and currency inconvertibility. The Nigerian government policy to stimulate the national economy through developing local content and Nationalization policy implemented in 1970s could be responsible for this. Despite the spread of globalization, countries usually 'protect' companies that are wholly or significantly owned by their nationals from competitions that are capable of stifling their growth. Insurgency is the second most likely political risk factor that could affect the corporate performance of multinational construction companies operating in the North-Eastern Nigeria. It has $3.80 \mathrm{EV}$ and 15.84\% PVE and its components are terrorism, kidnapping, sabotage and destructions. The sabotaging activity of Boko Haram sect in addition to kidnap-for-ransom that is prevalent in the NE explains this risk factor. 
Table 1: Factor Matrix (loading) of Level of Frequency of Political Risk Occurrence.

\begin{tabular}{|c|c|c|c|c|c|c|}
\hline \multicolumn{2}{|l|}{ Factor Components } & 1 & 2 & 3 & 4 & \\
\hline \multicolumn{2}{|l|}{ Expropriation } & .532 & & & & \\
\hline \multicolumn{2}{|l|}{ Confiscation } & .783 & & & & \\
\hline \multicolumn{2}{|l|}{ Contract Repudiation } & .739 & & & & \\
\hline \multicolumn{2}{|l|}{ Tax Restriction } & .673 & & & & \\
\hline \multicolumn{2}{|l|}{ Import Restriction } & .842 & & & & \\
\hline \multicolumn{2}{|l|}{ Export Restriction } & .407 & & & & \\
\hline \multicolumn{2}{|l|}{ Currency Inconvertibility } & -.577 & & & & \\
\hline \multicolumn{2}{|l|}{ Terrorism } & & .946 & & & \\
\hline \multicolumn{2}{|l|}{ Kidnapping } & & .852 & & & \\
\hline \multicolumn{2}{|l|}{ Sabotages } & & .865 & & & \\
\hline \multicolumn{2}{|l|}{ Destructions } & & .524 & & & \\
\hline \multicolumn{2}{|l|}{ Insurrections } & & & .874 & & \\
\hline \multicolumn{2}{|l|}{ Revolutions } & & & .793 & & \\
\hline \multicolumn{2}{|l|}{ Civil Wars } & & & -.594 & & \\
\hline \multicolumn{2}{|l|}{ Coup D'état } & & & -.849 & & \\
\hline \multicolumn{2}{|l|}{ Change in Government } & \multicolumn{5}{|c|}{.839} \\
\hline \multicolumn{2}{|l|}{ Default in Payment } & \multicolumn{5}{|c|}{.836} \\
\hline \multicolumn{2}{|l|}{ Ownership Restrictions } & \multicolumn{5}{|c|}{.815} \\
\hline \multicolumn{2}{|l|}{ Personnel Restrictions } & \\
\hline \multicolumn{2}{|l|}{ Corruption } & \multicolumn{4}{|r|}{-.450} & .895 \\
\hline \multicolumn{2}{|l|}{ Bureaucratic Bottlenecks } & & & & & .814 \\
\hline \multicolumn{2}{|l|}{ Demonstrations } & & & & & .568 \\
\hline \multicolumn{2}{|l|}{ Riots } & & & & & -.770 \\
\hline $\begin{array}{ll}\text { Note: } & \text { Extraction Met } \\
& \text { Rotation Metho } \\
& \text { Rotation conver }\end{array}$ & $\begin{array}{l}\text { od: Principal Co } \\
\text { : Varimax with } \mathrm{F} \\
\text { ged in } 23 \text { iteration }\end{array}$ & $\begin{array}{l}\text { ponent } A \\
\text { aiser Nor }\end{array}$ & $\begin{array}{l}\text { alysis } \\
\text { alization }\end{array}$ & & & \\
\hline & Table & : Summ & ry of $\mathrm{Ta}$ & le I factor & r Load & \\
\hline Factor Name & Eigen Value & Per & entage 0 & Variance & & Cumulative PVE \\
\hline & & Exp & ained $(P$ & VE) & & \\
\hline Protectionism & 4.34 & $\overline{18.0}$ & & & & 18.08 \\
\hline Insurgency & 3.80 & 15.8 & & & & 33.92 \\
\hline Violent civil disorders & 3.70 & 15.4 & & & & 49.36 \\
\hline Regime volatility & 2.75 & 11.4 & & & & 60.83 \\
\hline Corruption & 2.11 & 8.8 & & & & 69.63 \\
\hline
\end{tabular}

Construction activities could be destroyed or workers attacked as an act of sabotage by Boko Haram or community members that may feel alienated as a way of communicating their grievances. Violent civil disorders are the third most likely political risk factor to occur and has $3.70 \mathrm{EV}$ and $15.44 \%$ PVE. Its components are insurrection, revolutions, civil wars and coup d'etat. The activities of ethnic militias, cattle rustling, famers/herders' clashes that are common in the NE region is deduced to be responsible for this risk factor. Also, the proximity of countries like Niger, Chad and Cameroun with their militias to the NE region states encourages proliferation of illegal fire arms. 
Illegal possession of fire arms is allegedly caused by poor border security and policing with these countries and it constitutes a security risk to economic activities in the NE region.

Regime volatility has $2.75 \mathrm{EV}$ and $11.46 \% \mathrm{PVE}$ and is the risk factor that has the fourth likelihood of occurrence in the NE region. The immunity of Nigerian political regimes to political, economic and religious forces is relatively low. For instance, ethnic and religious forces often expose the Nigeria state volatility during general elections. To multinationals construction companies that have fixed capital investment in plants/equipment and have trained local/expatriate staff, this is a serious political risk factor. Insurance corporations that underwrite these investments would bill the multinationals construction company higher premium due to the volatility and this will increase the cost of doing business in the NE region. The fifth political risk is corruption and it has $2.11 \mathrm{EV}$ and 8.81 PVE\%. Corruption and bureaucratic bottlenecks associated with doing business in Nigeria could be responsible for this. In Nigeria, government is more involved in formal construction contracting than corporate and individual clients. Consequently, the interface would expose them to corruption and bureaucratic bottlenecks that may be associated with doing business with government in Nigeria. Generally, the study reveals that risk factors caused by the society are higher than risks caused by host government. This is in agreement with the government policy of strengthening foreign direct investment (FDI) and has been making efforts at minimizing host government-related risks.

\section{IMPACT OF POLITICAL RISKS}

Table III shows the level of impact of the listed political risk factors on the corporate performance of the international construction companies. The table shows that terrorism, kidnappings and sabotages are the political risk factors with the highest impact on their operations in the region. This could reduce multinational construction company revenues and increase construction cost and delivery time. It shows that occurrence of risks and its impact do no complementary relationships. Protectionism and its components that had the highest frequency of occurrence did not appear in the first ten in terms of impact. The prevalence of the activities of Boko Haram sect could be the reason why terrorism, kidnappings, sabotages has high impact on the corporate operations of multinational construction companies operating in the NE region. Local and foreign mass media often report cases of suicide bombers targeting people on the streets and in their homes for killing. The kidnap of scores of secondary school female students in Chibok and Dapchi (both in Yobe State) by Boko Hara sect attest to the prevalence of terrorism, kidnappings, sabotages in the area. The kidnap of defenseless female students should be a security concern to multinational construction companies and their interests that are located in the NE region.

Others political risk factors that have high impact are corruption and change in government. Corruption has not been defeated to its barest minimal in Nigeria despite government interventions through Economic and Financial Crimes Commission (EFCC) and Independent Corrupt Practices Commission (ICPC). However, it may be argued that these interventions could have mitigated corruption to the fourth rank in the order of impact. Continuity of political programme continuity among successive regimes in Nigeria is relatively low especially in infrastructure development and financing. This could be one of the reasons why project abandonment is relatively common in Nigeria. Currency devaluations and coup d'etat have the least impact on multinationals construction companies operating in the NE region. The reasons for these risks' factors are not farfetched. In construction contracts administration, currency 
devaluation risks could be mitigated through making claims for price fluctuation especially contracts that allow payment in hard foreign currencies. The last coup d'etat in Nigeria occurred in 1993 and Nigeria has been practising democracy since 1999 without putsch. This is the longest time it has had without the military forcefully taking over the government and its occurrence might not divert government attention from NE due to destruction and security risks it poses to Nigeria interests. This could be the reason why its impact would be minimal on the corporate activities of multinational construction companies operating in the NE.

Table 3: Level of impact of political risk factors on the corporate practice of multinationals construction companies operating in the North-Eastern Nigeria

\begin{tabular}{lll}
\hline Political risk factors & Mean & Relative importance index (RII) \\
\hline Terrorism & 4.43 & 1 \\
Kidnapping & 4.24 & 2 \\
Sabotages & 3.95 & 3 \\
Corruption & 3.81 & 4 \\
Change in Government & 3.75 & 5 \\
Riots & 3.67 & 6 \\
Demonstrations & 3.62 & 7 \\
Delay in Payment & 3.62 & 7 \\
Revolutions & 3.61 & 8 \\
Expropriation & 3.57 & 9 \\
Civil Wars & 3.43 & 10 \\
Confiscation & 3.36 & 11 \\
Export Restrictions & 3.29 & 12 \\
Currency Inconvertibility & 3.26 & 13 \\
Bureaucratic Bottlenecks & 3.25 & 14 \\
Taxation Restrictions & 3.25 & 14 \\
Insurrections & 3.22 & 15 \\
Economic Position & 3.12 & 16 \\
Change in Government Priorities & 3.07 & 17 \\
Destructions & 3.05 & 18 \\
Import Restrictions & 3.01 & 19 \\
Personnel Restriction & 3.01 & 19 \\
Forex Restrictions & 2.96 & 20 \\
Scarcity of Forex & 2.93 & 21 \\
Cost Over-run & 2.92 & 22 \\
Ownership Restrictions & 2.86 & 23 \\
Bribery & 2.63 & 24 \\
Government Policies & 2.61 & 24 \\
Currency Devaluation & 2.53 & 25 \\
Coup d'état & 2.49 & 25 \\
\hline & $\mathbf{S}$ & . \\
\hline
\end{tabular}

Source: Adebiyi and Sanni (2018)

\section{CONCLUSIONS}

The study reveals that there are various political risk factors that affect corporate performance of international construction companies operating in the North East of Nigeria. The research sought to find the level of frequency and impact of political risk factors on the operations of international construction companies in the region. Upon analysis of collected data, it was discovered that terrorism, corruption, insurrections, sabotages and kidnapping were the 
political risk factors with the highest frequency of occurrence. This finding is in line with Gilbert (2014), Olaniyan (2015), Pérouse de Montclos (2014) who stated that the emergence of the religious sect "Boko Haram" in the region has brought about terrorist actions, kidnapping, sabotages and insurrection, this is in a bid to pursue their goal of eradicating foreign education and culture in the region.

Also, the study revealed that terrorism, kidnappings, sabotages, corruption and change in government had the highest impact on the corporate performance of these companies. This finding agrees with Ohihon (2016), Gilbert (2014), Ogbonnaya and Ehigiamusoe (2013), who stated that activities of Boko Haram sect have affected the operations of international companies in the area by kidnapping expatriates, sabotaging the development projects and causing civil unrest in the region to prevent development of the region. This research is limited to northeast Nigeria, its findings should not be generalized for entire Northern Nigeria. This research can be replicated to other regions of the country for an in-depth study of the subject matter. In view of the findings of this study, it is recommended that multinational construction companies operating in the NE region should partner with the federal, state and local governments to foster security and community relations programmes that are capable of protecting their interests from these political risks. It is also important for multinationals companies operating in the NE to deepen their community engagement programmes such as corporate social responsibilities. This would increase community-company relationship and reduce hostility to the company interests. Also, multinational companies deepen their insurance policies to adequately safeguard their investments from political risks.

\section{REFERENCES}

Aaron, K.K. (2010). Two theses on corporate social responsibility failure in the Niger-Delta Nigeria. In Aaron, K.K., and George, D. (eds.) Placebo as medicine: the poverty of development intervention and conflict resolution strategies in the Niger-Delta region of Nigeria. Port-Harourt: Kemulea publications, 158-177

Adebiyi, J. O., 2011. Managerial Perception of Political Risk by International Construction Companies Operating in Port Harcourt, Nigeria (Unpublished master's thesis), Northumbria University, UK.

Adetoro, R.A. (2012). Boko Haram insurgency in Nigeria as a symptom of poverty and political alienation. Journal of Humanities and Social Sciences. 3(5):21-26.

Alon, I., Gurumoorthy, R., Mitchell, M.C. and Steen, T. (2006). Managing micro political risk: A cross-sector examination. Thunderbird International Business Review, 48(5): 623-642.

Al Khattab, A., Anchor, J. and Davies, E. (2007). Managerial perceptions of political risk in international projects. International Journal of Project Management, 25(7), 734-743.

Aswathappa, K. (2008) International Business (3 $3^{\text {rd }}$ edn.). New Delhi: Tata McGraw Hill.

Baas, D. (2010). Approaches and challenges to political risk assessment: The view from export development in Canada. Risk Management, 12(2): 135-162.

Brink C. (2004). Measuring political risk: Risks to foreign investment. England, USA: Ashgate Publishing Limited.

Bohstedt, J. (2010). The politics of provisions: food riots, moral economy and market transition in England. Surrey: Ashgate publishing company. 
Burutai T. (2017). Insurgency and the role of the Army in creating conducive environment for Nigeria's Economic Development. Retrieved on 1st November, 2017 from https://www.vanguardngr.com/2017/08/economicimpact-boko-haram-terro-ne-estimated-9bn-buratai

Butler, K and Joaquin, D. (1998). A note on political risk and the required return on foreign direct investment. Journal of International Business Studies, 29(3): 599-608.

Choi, J., Chung, J., and Lee, D. (2010). Risk perception analysis: participation in Chinas water PPP market. International Journal of Project Management, 28(6): 580-592.

Czinkota, M. R., Knight, G., Liesch, P. W. and Steen, J. (2010). Terrorism and international business: A research agenda. Journal of International Business Studies, 41(5): 826-843.

De-Mortanges, C and Allers, V. (1996). Political risk assessment: Theory and the experience of Dutch firms. International Business Review, 5(3): 303-318.

Deng, X., Low, S. P., Li, Q. and Zhao, X. (2014). Developing competitive advantages in political risk management for international construction enterprises. Journal of Construction Engineering and Management, 140(9), 414.

Deng, X. P., and Low, S. P. (2013). Understanding the critical variables affecting the level of political risks in international construction projects. Korea Society of Civil Engineers Journal of Civil Engineering, 17(5): 895907.

Dikmen, I., Birgonul, M. T. and Han, S. (2007). Using fuzzy risk assessment to rate cost overrun risks in international construction projects. International Journal of Project Management, 25(7): 494-505.

Erkan, M. (2011). International energy investment law: Stability through contractual clauses. Amsterdam, The Netherlands: Kluwer Law International.

Gilbert, L.D. 2014. Prolongation of Boko Haram Insurgency in Nigeria: The International Dimensions. Research on Humanities and Social Sciences, 4(11): 150-156.

Hardcastle, D. A., Powers, P. R. and Wenocur, S. (2004). Community practice: Theories and skills for social workers. Oxford: Oxford University Press.

Hardcastle, C., Edwards, P. J., Akintoye, A. and Li, L. (2004). Critical success factors for PPP/PFI projects in the UK construction industry. Retrieved on $26^{\text {th }}$ June, 2014 from www.rics.org/site/

Hashmi, A. and Guvenli, T. (1992). Importance of political risk assessment functions in U.S. multinational corporations. Global Finance Journal, 3(2): 137-144.

Hood, J. and Nawaz, M. (2004). Political risk exposure and management in multi-national companies: Is there a role for the corporate risk manager? International Journal of Risk Management, 6(1):7-18.

Howell, L.D. (2001). The handbook of country and political risk analysis $\left(3^{\text {rd }} \mathrm{ed}\right.$.). Colorado, USA: Political Risk Services Group.

Howell, L. D. and Chaddick, B. (1994). Models of political risk for foreign Investment and trade. Columbia Journal of World Business, 29(3): 70-90.

Jakobsen, J. (2010). Old problems remain, new ones crop up: Political risk in the $21^{\text {st }}$ century. Business Horizons, 53(5): 481-490. 
Keillor, B, D., Wilkinson, T, J. and Owens, D. (2005). Threats to international operations: dealing with political risk at the firm level'. Journal of Business Research, 58(5): 629-635.

Kettis M. (2004). The challenge of political risk: Exploring the political risk management of Swedish multinational corporations (Unpublished Doctoral Dissertation). Stockholm University, Stockholm, Sweden.

Low, S. P., Liu, J. Y., and He, Q. S. (2009). External risk management practices of Chinese construction firms in Singapore. Korea Society of Civil Engineers Journal of Civil Engineering, 13(2): 85-95.

MIGA (2009). World investment and political risk. Washington: World Bank Group.

Minor, J. (2003). Mapping the new political risk. Risk Management Journal, 50(3): 16-22.

Mohammed, K. (2014). The message and methods of Boko Haram. Islamism, politics, security and the state in Nigeria, $9 \mathrm{Vol} /$ issue page

Morales-Rios, R., Gamberger, D., Smuc, T., and Azuaje, F. (2009). Innovative methods in assessing political risk of business internationalization. Research in International Business and Finance, 23(1): 144-156.

Ngwama, J. C. (2014). Kidnapping in Nigeria: An emerging social crime and the implications for the labour market. International Journal of Humanities and Social Science, 4(1): 133-145.

Obi, C. (2009). Nigeria's Niger-delta: understanding the complex drivers of violent oil related conflict. Council for Development of Social Science Research in Africa, Vol. 34(2): 103-128.

Ogbonnaya, U.M. and Ehigiamusoe, U.K. (2013). Niger Delta militancy and Boko Haram Insurgency: National security in Nigeria. Global Security Studies, 4(3): 1-14.

Ohihon, I. B. (2016). Boko Haram: Islamism, politics, security and the state in Nigeria. Politics and Religion Journal, 9(1): 135-137.

Okoli, A. C., \& Iortyer, P. (2014). Terrorism and humanitarian crisis in Nigeria: Insights from Boko Haram insurgency. Global Journal of Human-Social Science Research. 14(1): 38-50

Olaniyan, O. D. (2015). Effect of boko haram insurgency on The Nigerian education system. Journal of Research, 24(2): 1-9.

Omotola, J.S., Patrick, J.M. (2010) State response to the Niger-Delta question: the OMPADEC and NDDC compared, in, Aaron, K, K., \& George, D., (ed.), Placebo as medicine: the poverty of development intervention and conflict resolution strategies in the Niger-Delta region of Nigeria. Port-Harcourt: Kemulea Publications, Pp. 158-177.

Osumah O. (2013) Boko Haram insurgencies in Northern Nigeria and the vicious cycle of international security. Journal of Small Wars and Insurgencies. 1(3): 2-5

Pérouse de Montclos, M. A. (2014). Boko Haram: Islamism, politics, security and the state in Nigeria (p. 275). Leiden: African Studies Centre.

Public Administration Programme (PAP) (n.d.). Factor Analysis: Statistical notes of the North Carolina State University. Retrieved on $23^{\text {rd }}$ August, 2015 from http://faculty.chass.ncsu.edu/garson/PA765/factor.htm

Rice G and Mahmoud E. (1990). Political risk forecasting by Canadian firms. International Journal of Forecasting 6: $89-102$. 
Stosberg J. (2005) Political risk and the institutional environment for foreign direct investment in Latin America. Frankfurt: Peter Lang publishers.

Voelker, C., Permana, A., Sachs, T., Tiong, R. (2008) 'Political risk perception in Indonesian', Journal of Financial Management of Property and Construction, 13(1): 18-34.

Weber, C. (2010), 'Quantification of Political Risk in Energy Foresight - A Method Overview.', Retrieved in on $10^{\text {th }}$ August, 2015 from www.isisit.com/efonet/index.php?option=com_docman\&task=doc...gid.

Zayed, T., Amer, M., Pan, J. (2007) 'Assessing risk and uncertainty in Chinese highway projects using AHP', International Journal of Project Management, 26(4): 408-419.

Zhuang, L., Ritchie, R., and Zhang, Q. (1998). Managing business risks in China. Long Range Planning, 31(4): 606614. 